\title{
Augmented Reality-Based Media to Improve Disaster Preparedness for Junior High School Students
}

\author{
Dewi Kurnia Herowati ${ }^{1,2 *}$
}

\author{
${ }^{1}$ Science Education Department, Universitas Ngeri Yogyakarta, Indonesia \\ *Corresponding author. Email: dewikurnia.2019@student.uny.ac.id
}

\begin{abstract}
Kebumen is one of the districts located on the southern coast of Indonesia. The area has the potential for natural disasters, including earthquakes and tsunamis. Students are one of the elements vulnerable to disaster risk, so student preparedness needs improvement. This study aims to determine the effectiveness of augmented reality-based earthquake and tsunami disaster media in enhancing disaster preparedness for junior high school students. This research was conducted in Ambal District, Kebumen Regency. This research is quasi-experimental. The sampling technique was purposive sampling. The research subjects consisted of 32 control class students and 32 experimental students from grade VII 2021/2022. This study indicates that the augmented reality-based earthquake and tsunami disaster media can improve the disaster preparedness ability of moderate students with a score of 0.59 in the category. This is a good category with the observation of students' disaster preparedness abilities at meeting one and meeting two, which has increased by $0.17 \%$ from a good increase.
\end{abstract}

Keywords: Augmented reality, Disaster Preparedness, Earthquake, Tsunami

\section{INTRODUCTION}

Disasters are events that threaten and disrupt people's lives, resulting in casualties, environmental damage, property losses, and psychological impacts. Unpreparedness in dealing with disasters, especially in areas with high economic value, will cause huge losses [1][2]. Disaster events are almost impossible to predict accurately when, where and how big so that the preparedness of all elements of society in various regions is a basic need so that the impact of disaster risk can be minimized [2].

Earthquakes are physical phenomena or natural events generally characterized by shaking the earth. Earthquakes caused by the interaction of tectonic plates can cause tidal waves when they occur in the ocean, so Indonesia often experiences tsunamis. Some areas prone to tsunamis are the west coast of Sumatra, the south coast of Java, the north and south coasts of the Nusa Tenggara islands, the Maluku islands, the north coast of Irian Jaya, and almost all coastal areas Sulawesi coast [3].
Kebumen Regency is one of the disaster-prone areas in Central Java Province, namely landslide-prone, floodprone, drought-prone or clean water-prone, and tsunami-prone. Ambal District is one of the sub-districts located on the southern coast of Kebumen Regency, which can be an earthquake and tsunami. Even though this sub-district beach is used as a beach tourist attraction crowded with domestic tourists, it risks taking more victims.

Seeing the potential for earthquake and tsunamiprone areas, it is necessary to educate on disaster mitigation and simulations to understand the tsunami disaster zone area. This condition illustrates that the coastal community of Kebumen must always have preparedness against the threat of an earthquake and tsunami. Until now, no technology can accurately predict when and where an earthquake will occur. Kompas.com said that the potential for a tsunami on the southern coast of Java Island did not need to be responded to with excessive panic [4]. 
Most material and non-material losses in Indonesia are caused by earthquakes and tsunamis, although less frequent than floods or landslides. Given this, disaster education needs to be developed by schools, especially those in disaster-prone locations. Disaster education aims to reduce the impact of disasters. It is hoped that disaster education can change awareness and strengthen the character of the nation's successor, who is resilient to disasters.

Disaster education needs to be developed by schools, especially those located in disaster-prone locations. Disaster education aims to reduce the impact of disasters, including the potential for disasters and the history of disasters that have occurred in the area, forms of anticipation, increasing knowledge and awareness of disaster signs, impacts on individuals, families and communities, ways of handling in disaster conditions, how to save yourself how to survive in a disaster situation [5].

Disaster preparedness is one part of the disaster management process [6]. Disaster preparedness is an effort and activity carried out before a natural disaster occurs to respond quickly and effectively to situations/ situations when and immediately after a disaster occurs. Disaster preparedness is an effort that enables individuals, groups, and organizations to cope with the dangers of natural events by establishing a systematic emergency response structure and structure. The purpose of preparedness is to minimize casualties and damage to public service facilities [7]. Disaster Preparedness includes efforts to reduce risk, preparation of disaster emergency response plans, resource management, training in disaster-prone locations.

Preparedness is essential and essential because effective preparedness helps save lives, reduce injuries, limit property losses and minimize all kinds of disturbances caused by disasters. Latupeirisa and Pujianto [7] help students learn well and easily understand disasters; a learning media is needed. The learning media itself is a means to convey material. Students will more easily absorb the material when they feel interested in the lesson. If students feel interested in the study, it will arouse students' curiosity, and understanding the material will improve. To make students interested in a lesson, it is necessary to have interactive learning media by adjusting technological advances. One of the uses of technology in learning is Augmented Reality-based disaster media.

This interactive learning media is intended to make the teaching and learning process more efficient and exciting [8]. Augmented reality-based disaster preparedness is expected to represent the community, especially junior high school students, accurately. It is easy to get disaster information to reduce the existing risks. By applying augmented reality media, it is hoped that it can help students understand their concepts and use ICT to learn science in materials about disaster mitigation to improve students' disaster preparedness.

\section{RESEARCH METHOD}

The type of research used is a quantitative research using quasi-experimental methods. This research was carried out at SMP Negeri 1 Ambal in August 2021. The research subjects consisted of 32 control class students and 32 experimental class students from class VII in the 2021/2022 academic year. The purposive sampling technique carried out the sampling technique. The data collection method used is an online questionnaire via Google Form regarding earthquake and tsunami disaster preparedness. Data analysis used multivariate analysis of variance.

\section{DISCUSSION}

Augmented Reality is an Android application as a primary electronic learning media with an apk file format. This Apk file can be installed on devices with Android OS and then run according to its use as an electronic essential learning medium. This basic electronic Augmented Reality application can run on all versions of Android Gingerbread with 512 RAM and a minimum 2 Megapixel camera.

This electronic AR application is deployed by downloading the application on the already available link. Augmented Reality technology invites students to think in real terms by displaying 3D animations of earthquake and tsunami disasters that resemble their original form. The primary electronic Augmented Reality learning media was developed through several stages, namely the analysis stage, the design stage, the implementation stage, and the testing stage. The last stage is a trial of learning media to class VII students to determine user assessments' response and improve students' disaster preparedness. Hypothesis testing to assess student disaster preparedness seen from the disaster preparedness questionnaire scores used is an online questionnaire via Google Form.

The results of field trials on augmented reality-based earthquake and tsunami disaster media were conducted with 32 students. The trial was conducted to determine the improvement of students' disaster preparedness using the media for the earthquake and tsunami disaster based on augmented reality media. Measurement of disaster preparedness ability is done by filling out a questionnaire before using the augmented reality-based earthquake and tsunami disaster media and after using the press. Students' preparedness for earthquakes and tsunamis consists of three parameters: 1) knowledge and attitudes, 2) emergency planning, 3) early warning system, and 4) resource mobilization. The four parameters are interrelated in individual readiness.

Earthquake and tsunami disasters are prone to occur on the southern coast of Kebumen, influenced by the geographical location of the area facing the Indian 
Ocean, which has the potential for earthquakes and tsunamis to occur. One of the most dangerous places during the earthquake and tsunami disaster is the school. It is one of the important buildings that becomes a gathering place for many individuals, especially during school hours.

\subsection{Disaster preparedness knowledge and attitude}

The results of data analysis after using augmented reality media showed that the level of students' knowledge was included in the understanding category. Students' average knowledge in dealing with earthquakes and tsunamis is $82.7 \%$ on a scale of $0-100$. Then, the attitude of disaster preparedness students showed $79.8 \%$. Geographical variables have been identified as essential determinants of disaster preparedness. A more extended stay in the community increases local knowledge about environmental risks, natural environment, and hazards. This raises awareness of the disaster and encourages preparatory activities [9]. Similarly, living in or near a hazard area implies better knowledge of hazard risks and consequently increases preparedness measures [9].

\subsection{Disaster Action Plan}

The emergency response plan for students is a form of anticipation carried out in reducing disaster risk; there are four indicators, including 1) necessary actions that must be taken, 2) items that need to be saved, 3) availability of maps, evacuation routes, 4) availability of media supporters. Careful planning during a data emergency minimizes the risk that a disaster will pose.

SMP Negeri 1 Ambal has a good plan. This is indicated by the student's choice of the statement of the emergency response plan at the point of action taken, namely following self-rescue, by $83.6 \%$. On the indicators of goods that need to be saved, the availability of maps, evacuation routes, and supporting media is an average of $79.92 \%$ because they are located between 65-79. Preparedness planning aims to ensure quick and appropriate action in the event of a disaster, by integrating and considering disaster management systems adapted to local conditions [10]. Preparedness planning ensures prompt and appropriate action in a disaster by integrating and considering disaster management systems adapted to local conditions.

\subsection{Disaster Warning System}

Preparedness is essential and must be built in every community group. Disaster prevention is one of the focuses in schools by empowering students to understand the warning signs of a disaster and the steps that can be taken to reduce disaster risk [11].

According to the researcher, students' preparedness in dealing with earthquake and tsunami disasters [12] based on a disaster warning system is in the ready category because respondents in this study are aware of a traditional tsunami warning system (kentongan, bell, drum, etc ) [11].

However, a tsunami warning system in sirens is not yet available in three sub-districts in Kebumen Regency. If there must be a disaster warning system using a siren in areas with potential earthquakes and tsunamis. When the siren sounds automatic, residents will move away from the beach or run to high places if they hear there is a tsunami danger, will go to the evacuation site when they hear a tsunami warning sign, will be calm or not panic when they hear a tsunami warning sign [13] [14].

\subsection{Mobilization of resources}

Resource mobilization in the context of student preparedness is the ability of schools to mobilize resources for students, teachers, and other school members and provide funds, facilities, and infrastructure for emergencies [14]. In ensuring disaster preparedness, schools must prepare adequate human resources, facilities, infrastructure, and finances in their management. $87.1 \%$ of junior high school students had attended training on disaster preparedness and emergency response management, but only $46 \%$ were members of the school's involvement team in the disaster preparedness network. In the Resource mobilization parameter, it is in the Not Ready category. However, after using augmented reality media about the earthquake and tsunami disaster, the response parameter of the disaster warning system increased to $79.3 \%$ [14].

The research results on the effectiveness of $A R$ learning media are stated to be quite effective because they can improve disaster preparedness. It was found that the value of disaster preparedness did increase, but there were still 8 out of 32 students or $40 \%$ of students whose scores were below the average. The magnitude of the increase was based on the partial eta square; the experimental class was only 8.8 percent. Higher than the control class. Augmented reality-based earthquake and tsunami disaster media can improve students' disaster preparedness skills with a score of 0.59 in the medium category. This is reinforced by observing students' disaster preparedness abilities at meeting one and meeting two, which increased by $20.17 \%$ from the pretty good to good category. 
Table 1. Percentage disaster preparedness of Student

\begin{tabular}{|l|c|c|c|c|}
\hline \multirow{2}{*}{ Parameters } & \multicolumn{2}{|l|}{ Percentage disaster preparedness of Student } & Category \\
\cline { 2 - 5 } & Meeting 1 & Meeting 2 & Average (\%) & Good \\
\hline Knowledge and attitude & 63 & 80,25 & 71,625 & Good \\
\hline Emergency response plan & 56,75 & 79,5 & 68,125 & Good \\
\hline Endemic warning system & 55,25 & 75,75 & 65,5 & Good \\
\hline Resource mobilization & 46 & 79,3 & 62,65 & \\
\hline
\end{tabular}

The research results on the effectiveness of $A R$ learning media are stated to be sufficiently compelling because it can improve disaster preparedness. It was found that the value of disaster preparedness is indeed improving, but there are still 8 out of 32 students or $40 \%$ of students whose scores are below average. The improvement is based on partial eta square; the experimental class is only 8.8 percent higher than the control class. Disaster media earthquakes and tsunami based on augmented reality can improve the ability of disaster preparedness of students with a score of 0.59 in the medium category. This is reinforced by the observation of the disaster preparedness abilities of students at the 1 st meeting and 2nd meeting, which increased by $20.17 \%$ from the good enough to good category.

\section{CONCLUSION}

Disaster media earthquakes and tsunami based on augmented reality can improve the ability of disaster preparedness of students with a score of 0.59 in the medium category.

\section{REFERENCES}

[1] www.ejurnal.stmik-budidarma.ac.id

[2] BNPB. 2016, Risiko Bencana Indonesia.

[3] Yudhi Gunardi, M. Syaom Barliana. DISASTER RESPONSE MOSQUE: A Mosque as a Center for The Rescue of The Ummah. Master of Architecture, Universitas Pendidikan Indonesia, Bandung, Indonesia,2021.

https:/ejournal.upi.edu/index.php/JodieBNPB. 2016, Risiko Bencana Indonesia.

[4] Noegi Noegroho, Spatial plan based on disaster mitigation in the city of Mukomuko, Bengkulu, IOP Conference Series: Earth and Environmental Science, 2020 https://doi.org10.1088/1755-1315/426/1/012070

[5] Rachmawati Rachmawati, Rosi Novita, The Effect of Disaster Management Education on Mother's
Under Five Preparedness Facing Floods in Aceh Province, Open Access Macedonian Journal of Medical Sciences, 2021 https://doi.org/10.3889/oamjms.2021.6455.

[6] O S Hardi, D Darsihardjo, E Ningrum, N Nandi, geographic skills of elementary school students in solving emergency flood response problems, IOP Conference Series: Earth and Environmental Science, 2018. doi :10.1088/1755-1315/145/1/012051

[7] V P S Latupeirisa, Pujianto. Level of earthquake disaster preparedness and its integrity in natural science learning: A literature review, Journal of Physics: Conference Series, 2020 doi:10.1088/17426596/1440/1/012093.

[8] es.scribd.com

[9] Roman Hoffmann, Raya Muttarak. Learn from the Past, Prepared for the Future: impacts of education and experience on disaster preparedness in the Philippines and Thailand. World Development, 2017. https://doi.org/10.1016/j.worlddev.2017.02.016

[10] Irfiani Triastari, Siti Irene Astuti Dwiningrum, Sovia Husni Rahmia. "Developing Disaster Mitigation Education with Local Wisdom: Exemplified in Indonesia Schools", IOP Conference Series: Earth and Environmental Science, 2021 DOI: 10.1088/1755$\underline{1315 / 884 / 1 / 012004}$

[11] Deri Andespa, Ahmad Fauzi, Analysis of senior high school student preparedness in dealing with earthquake disaster in the Mentawai island, Journal of Physics: Conference Series, 2019 doi. 10.1088/17426596/1185/1/012081

[12] D E Elfiana, Madlazim, E Hariyono, Munasir., Development of The OrSAEv Learning Materials: preliminary study of student's knowledge about earthquake and tsunami mitigation, Journal of Physics: Conference Series, 2019 DOI: 10.1088/17426596/1417/1/012083 
[13] Ruri Maiseptya Sari, Hanifah Hanifah, Vike Pebri Giena, the influence of knowledge and disaster warning and the preparation of high school students in facing earthquake and tsunami, Nurse and Health: Jurnal Keperawatan, $2019 . \quad$ DOI: https://doi.org/10.36720/nhjk.v8i2.123

[14] A P Ira, S Purwantara, school community preparedness in anticipation of earthquake and tsunami threats in temon sub-district, IOP Conference Series: Earth and Environmental Science, 2021. doi:10.1088/1755-1315/884/1/012046

[15] Putra Agina Widyaswara Suwaryo, Dela Gustia Rahma, Barkah Waladani, Aprilia Safaroni, community preparedness to reduce risk disaster of tsunami, Babali Nursing Research, 2021. https://doi.org/10.37363/bnr.2021.2146 